REVIEW

\title{
RBP4: a controversial adipokine
}

\author{
Primoz Kotnik ${ }^{1,2}$, Pamela Fischer-Posovszky ${ }^{1}$ and Martin Wabitsch ${ }^{1}$ \\ ${ }^{1}$ Division of Pediatric Endocrinology and Diabetes, Department of Pediatrics and Adolescent Medicine, University of Ulm, Ulm, Germany and ${ }^{2}$ Department \\ of Endocrinology, Diabetes and Metabolism, University Children's Hospital Ljubljana, UKC Ljubljana, Ljubljana, Slovenia \\ (Correspondence should be addressed to M Wabitsch; Email: martin.wabitsch@uniklinik-ulm.de)
}

\begin{abstract}
Adipose tissue is an endocrine organ secreting biologically active factors called adipokines that act on both local and distant tissues. Adipokines have an important role in the development of obesity-related comorbidities not only in adults but also in children and adolescents. Retinol binding protein 4 (RBP4) is a recently identified adipokine suggested to link obesity with its comorbidities, especially insulin resistance, type 2 diabetes (T2D), and certain components of the metabolic syndrome. However, data, especially resulting from the clinical studies, are conflicting. In this review, we summarize up-to-date knowledge on RBP4's role in obesity, development of insulin resistance, and T2D. Special attention is given to studies on children and adolescents. We also discuss the role of possible confounding factors that should be taken into account when critically evaluating published studies or planning new studies on this exciting adipokine.
\end{abstract}

European Journal of Endocrinology 165 703-711

\section{Introduction}

With the epidemics of obesity, much effort has been put into unraveling the mechanisms by which obesity causes its comorbidities $(1,2)$. Biologically active factors secreted from the adipose tissue have both local and systemic effects on the metabolism, immune system, and endocrinology. These factors are called adipokines and adipose tissue is regarded as an endocrine organ. It is well established that adipokines have an important role in the development of obesity-related comorbidities in children, adolescents, and adults (2-7).

Retinol binding protein 4 (RBP4) is a recently identified adipokine (8) that has caused a controversial scientific discussion on whether and how it links to adiposity, insulin resistance, and type 2 diabetes (T2D) (9-11).

\section{The discovery of RBP4 as a possible adipokine}

The role of RBP4 in obesity and insulin resistance was first discovered by Barbara Kahn's group. They found that mice with an adipose-specific knockout of GLUT4 (adipose GLUT4 ${ }^{-1-}$ mice) developed insulin resistance in muscles and liver (12). Mice with adipose-specific overexpression of GLUT4 showed an increased capacity for glucose clearance (13). These data suggest a factor secreted from the adipocytes that causes the observed changes in the muscle and liver (12).
Using DNA arrays, it was shown that expression of RBP4 is increased in adipose tissue of adipose GLUT4 $^{-1-}$ mice and reduced in mice overexpressing adipose GLUT4. Changes in serum RBP4 levels correlated with changes observed in the adipose tissue mRNA levels (8). RBP4 serum levels were also significantly increased in additional five mouse models of obesity and insulin resistance (8). Furthermore, transgenic overexpression of human RBP4 or injection of recombinant RBP4 in normal mice caused insulin resistance (8).

Increased serum RBP4 levels induced hepatic expression of the gluconeogenic enzyme phosphoenolpyruvate carboxykinase and impaired insulin signaling in the muscle (8). On the other hand, mice with heterozygous or homozygous RBP4 knockout had increased insulin sensitivity (8). By using insulinsensitizing medication, the PPAR $\gamma$ agonist rosiglitazone, a normalization of insulin sensitivity in adipose GLUT4 $^{-1-}$ mice and a decrease in their RBP4 levels in the adipose tissue and in serum, but not in the liver, could be shown (8). In addition, fenretinide, a synthetic retinoid that increases urinary excretion of RBP4, normalized serum RBP4 levels and improved insulin resistance and glucose intolerance in mice with obesity (8).

Based on these studies, it was suggested that RBP4 is an adipocyte-derived factor that acts on muscle and/or liver, in either retinol-dependent or retinol-independent way, affecting insulin sensitivity $(8,12)$. 


\section{Characteristics of RBP4}

RBP4 belongs to the lipocalin family of proteins that transport small hydrophobic molecules (14). The RBP4 gene is located on chromosome 10 (10q23-q24) near the region that has been linked to increased fasting glucose levels in European Caucasians and to T2D in Mexican-Americans $(15,16)$. It encodes a protein of 201 amino acids and has a molecular mass of $\sim 21 \mathrm{kDa}$ $(17,18)$. Liver has the highest expression level of RBP4; however, adipose tissue has the second highest rate of expression, i.e. $20-40 \%$ of that found in the liver (19). In adipose tissue, RBP4 is expressed in mature, lipidladen adipocytes (20).

RBP4 is a transport protein for retinol (vitamin A) in the circulation. It transports retinol from the liver to the peripheral tissues (21). Plasma RBP4 levels positively correlate with retinol levels (22). Therefore, subject's retinol status can influence circulating RBP4 levels. In clinical studies, RBP4-to-retinol ratio is used to correct for retinol status of the investigated subject (22).

Of importance, RBP4 does not interact only with retinol. Formation of a complex with transthyretin a carrier of thyroid hormone and retinol - prevents glomerular filtration of RBP4 and its subsequent excretion through the kidney (23). It is debatable whether increased transthyretin levels and/or enhanced RBP4 to transthyretin interaction can result in decreased renal clearance of RBP4 and consequently its increased circulating levels $(24,25)$. Circulating RBP4 levels are also influenced by iron and ferritin status as discussed later in the text (26).

At the level of peripheral tissues, RBP4 may act directly by binding to cell surface receptors (27-29) or through retinoic acid on retinoic acid receptors and retinoic acid-X receptors (30). With respect to the association between RBP4 and insulin resistance/T2D, a recently identified RBP4 cell surface receptor, stimulated by retinoic acid gene homolog 6 (STRA6), seems to be of special importance (29). SNPs in this transmembrane protein, which has high affinity for RBP4 and is a major mediator of intracellular retinol uptake, have been identified that are linked to T2D (31).

\section{RBP4, obesity, and body fat distribution: clinical studies}

Serum RBP4 levels are increased and positively correlated with body mass index (BMI) in obese nondiabetic and diabetic subjects $(8,32)$. Several RBP4 gene variants have been determined that associate with the level of adiposity and the predisposition for visceral accumulation of adipose tissue (Table 1). Two SNPs (SNP (risk allele) rs10882283(G) and rs10882273(C)) are associated with increased BMI and waist-to-hip ratio (33). Regulatory RBP4 SNP (SNP (risk allele) rs3758539(A)) resulting in overexpression of RBP4 and increased susceptibility for obesity, as a consequence of increased adipogenesis, has been reported (34). In addition, a higher visceral RBP4 mRNA expression has been reported in diabetes risk RBP4 haplotype carriers (SNP (risk allele) rs3758539(G), c. $248+44 \mathrm{~T}>\mathrm{C}$, rs12265684(G), and rs10882273(C)) (33).

In addition to increased BMI and whole-body fat content, increased circulating RBP4 levels are linked to increased visceral adipose tissue content (35-39). RBP4 is preferentially expressed in visceral fat when compared with subcutaneous fat (40). Omental adipose tissue is an important source of RBP4 in severely obese patients (39). In a recent study, higher waist circumference and waist-to-hip ratio were associated with higher RBP4 levels and markers of systemic inflammation (41).

Significant decrease in weight, achieved by diet, exercise, or bariatric surgery, leads to a decrease in circulating and/or adipose tissue RBP4 levels $(9,32,42-44)$. The changes in RBP4 levels in non-diabetic subjects during weight loss were significantly correlated with the amount of visceral fat loss but were not associated with the amount of total body fat loss or abdominal subcutaneous fat loss (43). A decrease in serum RBP4 levels achieved by exercise training predicts the improvement in insulin sensitivity with greater specificity than leptin, adiponectin, interleukin-6, or C-reactive protein (32).

These studies suggest an association between adiposity, especially visceral, with increased levels of circulating and adipose tissue RBP4 levels. A decrease in weight and/or intensive exercise results in decreased RBP4 levels and correlates with the improvement in insulin sensitivity.

\section{RBP4 in insulin resistance and T2D: clinical studies}

Even before RBP4 was considered a possible adipokine, there were reports on increased levels of RBP4 in the serum or urine of subjects with T2D. However, causality was not suggested at this time point $(45,46)$.

Serum RBP4 levels are increased in subjects with impaired glucose tolerance, T2D, and correlate inversely with insulin sensitivity in non-diabetic subjects with a family history of T2D $(8,32,35,47)$. Circulating RBP4 levels correlate with the degree of insulin resistance in these subjects and relationship is independent of obesity (32).

Several RBP4 genetic variants are associated with insulin resistance and T2D (Table 1). Two haplotypes (SNP (risk allele): rs3758538(A), rs3758539(G), rs10882283(G), c248+44T $>$ C (T), rs12265684(G), rs10882273(C); and rs3758539(G), 390C $>\mathrm{G}(\mathrm{G})$, $406 \mathrm{~T}>\mathrm{C}(\mathrm{T}), \quad \operatorname{rs} 36014035(\mathrm{G}), \quad \mathrm{rs} 12265684(\mathrm{G})$, rs34571439(T), rs12766992(G), rs10882273(C)) are significantly increased in Caucasians with T2D when compared with healthy controls $(33,48)$. Four SNPs in Mongolian population (SNP (risk allele): rs3758539(A), 
Table 1 SNPs in RBP4 and STRA6 genes associated with obesity, visceral accumulation of adipose tissue, insulin resistance (IR) and T2D.

\begin{tabular}{|c|c|c|c|c|}
\hline $\begin{array}{l}\text { Gene/ } \\
\text { condition }\end{array}$ & Finding (references) & OR $(95 \% \mathrm{Cl})$ & SNP (risk allele) & Haplotype \\
\hline \multicolumn{5}{|l|}{ RBP4 } \\
\hline \multirow[t]{4}{*}{ Obesity } & $\begin{array}{l}\text { Increased BMI and waist-to-hip ratio in } \\
\text { non-diabetic Caucasians (33) }\end{array}$ & $\mathrm{N} / \mathrm{A}$ & $\begin{array}{l}\text { rs10882283(G) } \\
\text { rs10882273(C) }\end{array}$ & \\
\hline & $\begin{array}{l}\text { Increased BMI in Japanese men and women } \\
\text { and Mongolian women (34) }\end{array}$ & N/A & rs3758539(A) & \\
\hline & $\begin{array}{l}\text { Diabetes-risk haplotype associated with } \\
\text { increased RBP4 mRNA expression in } \\
\text { visceral adipose tissue }(33,48)\end{array}$ & $\mathrm{N} / \mathrm{A}$ & & $\begin{array}{l}\text { rs3758539(G) } \\
\mathrm{c} .248+44 \mathrm{~T}>\mathrm{C} \\
\mathrm{rs} 12265684(\mathrm{G}) \\
\mathrm{rs} 10882273(\mathrm{C})\end{array}$ \\
\hline & $\begin{array}{l}\text { Increased fasting plasma insulin in non-diabetic } \\
\text { Caucasians (33) }\end{array}$ & $\mathrm{N} / \mathrm{A}$ & rs10882273(C) & \\
\hline \multirow[t]{3}{*}{ IR } & $\begin{array}{l}\text { Higher mean fasting plasma insulin and } 2 \mathrm{~h} \text { plasma } \\
\text { glucose in non-diabetic Caucasians (33) }\end{array}$ & $\mathrm{N} / \mathrm{A}$ & & $\begin{array}{l}\text { rs3758538(A) } \\
\text { rs3758539(G) } \\
\text { rs10882283(G) } \\
\text { c248_44T_C(T) } \\
\text { rs12265684(G) } \\
\text { rs10882273(C) }\end{array}$ \\
\hline & Reduced insulin secretion in Caucasians (48) & $\mathrm{N} / \mathrm{A}$ & $\begin{array}{l}\text { rs3758539(A) } \\
\text { rs34571439(G) }\end{array}$ & \\
\hline & Reduced insulin sensitivity (48) & N/A & $+390(\mathrm{G})$ & \\
\hline \multirow[t]{5}{*}{ T2D } & T2D in Caucasians (33) & $1.37(1.05-1.79)$ & & $\begin{array}{l}\text { rs3758538(A) } \\
\text { rs3758539(G) } \\
\text { rs10882283(G) } \\
\text { c248+44T>C(T) } \\
\text { rs12265684(G) } \\
\text { rs10882273(C) }\end{array}$ \\
\hline & T2D in Caucasians (48) & $\mathrm{N} / \mathrm{A}$ & & $\begin{array}{l}\text { rs3758539(G) } \\
390 \mathrm{C}>\mathrm{G}(\mathrm{G}) \\
406 \mathrm{~T}>\mathrm{C}(\mathrm{T}) \\
\text { rs36014035(G) } \\
\text { rs12265684(G) } \\
\text { rs34571439(T) } \\
\text { rs12766992(G) } \\
\text { rs10882273(C) }\end{array}$ \\
\hline & T2D in South Indian population (31) & $1.69(1.51-2.48)$ & & $\begin{array}{l}\text { rs3758538(C) } \\
\text { rs3758539(T) } \\
\text { rs36014035(G) } \\
\text { rs34571439(T) }\end{array}$ \\
\hline & Increased risk of T2D in Mongolians (49) & $\begin{array}{l}1.58(1.15-2.23) \\
1.61(1.26-2.07) \\
1.63(1.19-2.09) \\
1.63(1.22-2.25)\end{array}$ & $\begin{array}{l}\text { rs3758539(A) } \\
\text { rs7094671(T) } \\
\text { rs12265684(C) } \\
7542 T>\operatorname{del}(\text { del })\end{array}$ & \\
\hline & $\begin{array}{l}\text { Increased circulating RBP4 levels in T2D } \\
\text { Mongolian subjects (49) }\end{array}$ & $\mathrm{N} / \mathrm{A}$ & rs3758539(A) & \\
\hline \multicolumn{5}{|l|}{ STRAG } \\
\hline \multirow[t]{3}{*}{ T2D } & T2D in South Indian population (31) & $\begin{array}{l}0.79(0.69-0.91) \\
0.81(0.71-0.93) \\
0.74(0.62-0.89)\end{array}$ & $\begin{array}{l}\text { rs974456(T) } \\
\text { rs736118(A) } \\
\text { rs4886578(A) }\end{array}$ & \\
\hline & T2D in South Indian population (31) & $1.23(1.08-1.40)$ & & $\begin{array}{l}\text { rs974456(C) } \\
\text { rs736118(G) } \\
\text { rs4886578(G) }\end{array}$ \\
\hline & T2D in South Indian population (31) & $0.73(0.59-0.89)$ & & $\begin{array}{l}\text { rs974456(T) } \\
\text { rs736118(A) } \\
\text { rs4886578(A) }\end{array}$ \\
\hline
\end{tabular}

N/A, not available.

rs7094671(T), rs12265684(C), and 7542T $>$ del(del)) and a haplotype in South Indian population (rs3758538(C), rs3758539(T), rs36014035(G), and rs34571439(T)) have also been determined that are associated with T2D $(31,49)$. Haplotype (SNP (risk allele)) rs3758538(A), rs3758539(G), rs10882283(G), $\mathrm{c} 248+44 \mathrm{~T}>\mathrm{C}(\mathrm{T}), \mathrm{rs} 12265684(\mathrm{G}), \mathrm{rs} 10882273(\mathrm{C}))$ is also associated with higher mean fasting plasma insulin and $2 \mathrm{~h}$ plasma glucose in OGTT in non-diabetic Caucasians (33). In Mongolians, SNP in the regulatory 
region of the RBP4 gene (SNP (risk allele) rs3758539(A)) is associated with increased circulating RBP4 levels in T2D subjects (49). Recently, three SNPs (SNP (risk allele): rs974456 (T), rs736118 (A), and rs4886578 (A)) and two haplotypes (SNP (risk allele): rs974456(C), rs736118(G), rs4886578(G) and (rs974456(T), rs736118(A), rs4886578(A)) in the gene encoding a high-affinity cell surface receptor for RBP4, STRA6, have been identified that are associated with T2D (31).

In addition to decreased insulin sensitivity, a negative effect of RBP4 on the secreting function of the beta cell is suggested. Increased circulating RBP4 levels are namely negatively associated with insulin secretion, especially in obese subjects, and SNPs in the RBP4 gene (SNP (risk allele): rs3758539(A) and rs34571439(G)) were identified that are also associated with reduced insulin secretion in Caucasians $(11,48)$.

Weight loss and exercise decrease RBP4 levels in subjects with insulin resistance and T2D $(32,50)$. The decrease is specifically linked to those with improved insulin sensitivity (32). Therapy with insulin-sensitizing agent rosiglitazone also decreases circulating RBP4 levels (37). At the level of the adipose tissue, slight weight loss, achieved by caloric restriction, results in slight decrease in adipose tissue RBP4 expression. This is, however, not reflected in circulating RBP4 levels (9).

Altogether, these data suggest that RBP4 is increased in the early stages of the development of T2D. It could be used as an additional marker for early detection of subjects predisposed to develop T2D enabling an early and vigorous intervention. Since levels of RBP4 decrease with weight loss and exercise, RBP4 could also be used as an additional parameter in the estimation of the success of the intervention.

Circulating RBP4 levels also correlate with other components of the metabolic syndrome (32, 51-54). It is suggested that RBP4 is a predictor of atherosclerosis and its clinical manifestations - cardiovascular diseases. Circulating RBP4 levels are positively associated with intima media thickness, an established parameter of atherosclerosis (55). Increased RBP4 levels are found in subjects with cerebral infarction, associated with earlier cardiovascular disease, and increased risk of incident coronary disease (56-58). The positive association with the metabolic syndrome and its complications was, however, not determined in all studies $(59,60)$. In addition, determining circulating RBP4 levels does not provide any additive value, to the commonly accepted risk factors, in determining the risk of future coronary artery disease in both female and male (58).

\section{RBP4 in childhood/adolescent obesity and insulin resistance}

The role of RBP4 in obesity and its comorbidities was also investigated in children and adolescents of different ethnic backgrounds. In prepubertal and early pubertal children and in adolescents, serum RBP4 levels are increased in those with obesity (61-67). In prepubertal and early pubertal children, RBP4 and RBP4-to-serum retinol ratio were positively correlated with BMI, visceral accumulation of adipose tissue, components of the metabolic syndrome, and inflammatory markers $(61,62,64,66,67)$. Of importance, dietary intake of retinol was considered in the analysis in some studies $(61,63)$. In lean children, BMI is, however, not correlated to circulating RBP4 levels (68).

Plasma RBP4 levels are also increased in obese children and adolescents with glucose intolerance compared with those with normal weight. There is a negative correlation between skeletal muscle insulin resistance index and RBP4 plasma levels (64). Homeostasis model assessment (HOMA) index is positively correlated with RBP4 serum levels in obese but not in lean children (68). In a retrospective study, an increase in RBP4 with time was associated with increased odds of worsening insulin resistance and this association was independent of changes in adiposity (69).

In small for gestational age newborns that are predisposed to insulin resistance, RBP4 level in cord blood is, however, reduced. Birth weight, and not parameters of insulin sensitivity, is the major parameter determining circulating RBP4 levels in this population (70).

As in adults, in obese adolescents, RBP4 levels decrease with lifestyle intervention. This reduction is correlated to the magnitude of the decrease in inflammatory markers (62). These results were confirmed in a longitudinal follow-up study on prepubertal to early pubertal children where substantial weight loss resulted in reduced levels of RBP4 and RBP4-to-serum retinol. The decrease was in parallel with the decrease in blood pressure, triglycerides, insulin, and HOMA index and an increase in quantitative insulin check index (QUICKI) (63).

These data suggest that in children and adolescents, RBP4 levels could be linked to obesity and insulin resistance, although it must be emphasized that positive associations have not been shown in all studies (71). Longitudinal clinical studies on the role of this adipokine in the development of obesity-associated metabolic comorbidities are necessary in children and adolescents.

\section{Clinical studies showing lack of associ- ation between RBP4 levels and obesity and/or insulin-resistant states}

The associations between RBP4 levels, RBP4 gene expression, and measures of obesity or insulin resistance have, however, not been found consistently in clinical studies. Several studies found no correlation between circulating RBP4 levels, the level of obesity, and the amount and distribution of adipose tissue (9-11, 35, 72). In addition, several studies found no correlation 
between RBP4 adipose tissue mRNA expression and serum levels $(9,10,44,73)$.

In several studies, circulating RBP4 levels also did not correlate with insulin resistance, impaired glucose tolerance, T2D, or altered insulin secretion (10, 72, 74-77). In adipose tissue and muscle, insulin-sensitizing agent pioglitazone unexpectedly increased RBP4 gene expression (10). With regard to children, RBP4 levels do not significantly differ between prepubertal and pubertal children, despite the later being significantly more insulin resistant, indicating lack of causal association between insulin resistance and RBP4 serum levels in children and adolescents (68).

Some alternative explanations were therefore proposed for the observed positive correlations between $\mathrm{RBP} 4$, obesity, insulin resistance, and T2D. Increased circulating RBP4 levels in T2D subjects could be the result of decreased renal clearance of RBP 4 caused by different levels of renal insufficiency in these subjects (78-80). These studies are supported by the fact that patients with end-stage kidney failure have significantly higher circulating RBP4 levels than healthy controls and that serum creatinine levels independently predict RBP4 concentrations in both controls and patients with kidney failure (81). There is an ongoing debate on the possible influence of transthyretin on circulating RBP4 levels via RBP4's decreased renal clearance $(24,25)$. It is also proposed that imbalance between RBP4 and retinol might be the underlying cause for the observed association between RBP4 levels and systemic insulin resistance (22).

In addition, shortcomings in the methodology of measuring RBP4 levels are reported. RBP4 levels can already be influenced by the collection method. Plasma anticoagulants (heparin, EDTA, citrate, and lithium chloride) in collecting tubes alter the absolute amount of RBP4 immunoreactivity. The influence is unpredictable from subject to subject. Therefore, glass vacuum tubes without additives are suggested as an optimal collection container. Further, the design of RBP 4 antibodies used in the immunoassays and the design of the immunoassays itself can importantly influence the results. It is suggested that quantitative western blotting standardized to full-length RBP4 protein is the most reliable method to measure the levels of RBP4 (32).

\section{Sex-specific dimorphism of RBP4}

It is known that certain adipokines are expressed differently depending on the gender. Higher circulating levels of leptin and adiponectin are found in women $(82$, 83). On the contrary, higher levels of circulating RBP4 are described in men $(35,37,65,67,72)$. This dimorphism was, however, not shown in all studies (32, 73, 84, 85). Recently, higher RBP4 mRNA expression in adipose tissue was found in women when compared with men; this was, however, not reflected in the circulating levels (73).

It is suggested that sex-specific dimorphisms in circulating levels of adipokines can be related to direct effects of sex hormones on adipocyte expression and secretion (83). In case of RBP4, this possible mechanism is not supported by the fact that serum RBP4 levels are similar in pubertal and prepubertal subjects that significantly differ in levels of circulating sex hormones (68). However, higher circulating RBP4 levels were determined in male adolescents in comparison with female adolescents (67). A possible direct role of gonadotropins on the expression of RBP4 is also proposed, as circulating RBP4 levels are higher in postmenopausal compared with premenopausal women and in women older than 50 years when compared with those younger than 50 years $(35,86,87)$. Circulating RBP4 levels are increased in women with polycystic ovary syndrome (PCOS) and are correlated to increased levels of FSH and LH (88). In women with PCOS, RBP4 serum levels are positively correlated to serum levels of androgens (testosterone, 17-OH progesterone, and DHEA sulfate) (89). In addition, increased RBP4 mRNA

Table 2 Summary of findings on regulation of RBP4 expression and its effects in human adipocytes.

\begin{tabular}{|c|c|c|c|}
\hline Adipocyte type & Parameter & $\begin{array}{l}\text { RBP4 expression/ } \\
\text { secretion }\end{array}$ & Reference \\
\hline \multicolumn{4}{|l|}{ Regulation of human adipocyte RBP4 expression } \\
\hline $\begin{array}{l}\text { Primary human (female) adipocytes from mammary } \\
\text { adipose tissue }\end{array}$ & $\begin{array}{l}\text { TNF } \alpha \\
\text { PPAR gamma agonist } \\
\text { Metformin }\end{array}$ & $\begin{array}{l}\downarrow \\
\uparrow \\
\text { No effect }\end{array}$ & $(92)$ \\
\hline Primary human adipocytes and SGBS cells & $\begin{array}{l}\text { PPAR gamma agonist } \\
\text { Metformin }\end{array}$ & $\uparrow$ & $(10)$ \\
\hline $\begin{array}{l}\text { Primary human adipocytes from obese subjects } \\
\text { (visceral and subcutaneous depots) }\end{array}$ & $\begin{array}{l}\text { Iron donor } \\
\text { Iron buffer }\end{array}$ & $\uparrow$ & $(26)$ \\
\hline Primary human (female) adipocyte & Leptin & $\uparrow$ & $(73)$ \\
\hline Primary human (female) adipocyte & Estradiol & $\uparrow$ & $(90)$ \\
\hline \multicolumn{4}{|c|}{ Effects of RBP4 on insulin signaling in human adipocytes } \\
\hline $\begin{array}{l}\text { Primary human adipocyte from diabetic and } \\
\text { non-diabetic subjects }\end{array}$ & & $\begin{array}{l}\text { Inhibition of phosphoryl- } \\
\text { ation at the site of IRS } 1^{*}\end{array}$ & $(91)$ \\
\hline
\end{tabular}

*, Major finding

IRS1, insulin receptor substrate 1 
and protein levels were found in adipose tissue of women with PCOS. In cell culture experiments, estradiol and not androgens, however, directly increases the RBP4 mRNA expression, protein levels, and secretion of RBP4 into the culture media (90). Recently, it was proposed that another sex-dimorphic adipokine leptin directly stimulates RBP4 expression in human adipocytes (73).

RBP4 sex-specific dimorphism is also linked to iron metabolism. Serum ferritin levels are higher in men than in women and are positively associated with serum $\mathrm{RBP} 4$ concentration in humans. Iron depletion leads to a decrease in circulating RBP4 levels and an increase in insulin sensitivity (26).

\section{Studies on human adipocytes}

Despite intriguing findings from animal and clinical studies, there is still limited data on the mechanisms involved in RBP4 expression and secretion and its possible auto- and para-crine effects on the human adipocyte (Table 2).

While studying altered insulin signaling in adipocytes treated with RBP4, it was proposed that RBP4 inhibits phosphorylation at the site of the insulin receptor substrate 1 that may be responsible for integrating nutrient sensing with insulin signaling (91). In a study focusing on the role of inflammation in RBP 4 expression in human adipocytes, RBP4 was unexpectedly downregulated by tumor necrosis factor $\alpha(\mathrm{TNF} \alpha)(92)$. While studying the effect of commonly used anti-diabetic medications on RBP4 expression in human adipocytes, surprisingly an upregulation of RBP4 was determined with the use of PPAR $\gamma$ agonists troglitazone and pioglitazone $(10,92)$. Metformin had no effect on the expression of RBP4 (92). The same lack of effect was found in adipose tissue explants of humans treated with metformin (26) (Table 2).

However, in studies linking changes in RBP4 expression with changes in insulin sensitivity and iron status, it was determined that lactoferrin, an iron donor, led to a significantly increased expression of RBP4 and to increased release of RBP4 into the media in a dosedependant manner. Apotransferrin and deferoxamine, both iron buffers, significantly decreased the expression and release of RBP4, suggesting a link between RBP4, insulin resistance, and iron metabolism (26).

Very recently, it was shown that other adipokines could have a direct role in stimulating RBP4 expression in human adipocytes. Namely, treatment of adipocytes from human visceral adipose tissue explants with increasing doses of recombinant leptin is associated with increased RBP4 protein expression (73).

Further studies are thus needed to precisely determine the regulation of RBP4 expression and secretion on the level of the human adipocyte. In addition, interactions with other factors involved in adipose tissue insulin resistance need to be further explored.

\section{Conclusions}

RBP4 is an adipokine consistently associated with adiposity and insulin resistance in animal models (8, 12). It was also considered a promising adipokine in humans possibly linking adiposity, insulin resistance, T2D, and certain components of the metabolic syndrome (32, 33, 35, 47, 48, 51-54). However, in several clinical studies, associations and/or causality of observed RBP4 expression changes with these states could not be shown $(9-11,35,71,72,93)$. It seems that there are many confounding factors that affect the proposed correlations and should be taken into account when interpreting the results. In addition to differences in the genetic background of screened populations, gender ratios and age of the population studied have an important role in the interpretation and comparison of the data. Methodological differences in collection of the samples and determination of RBP4 levels must be considered (32). Confounding effects of retinol status, iron status, and kidney function also seem to be of importance and should be addressed in the design of future studies $(22,26,78)$. Additional studies on human adipocytes are needed to unravel the regulation of RBP4 expression and secretion and its auto- and para-crine effects.

The majority of clinical studies in children and adolescents, to date, support the hypothesis that RBP4 has a relevant role in obesity and the development of insulin resistance and T2D in this population (61-64, $67,68)$. RBP4 is an adipokine that seems to be involved in the early phases of the development of insulin resistance and other components of the metabolic syndrome. Therefore, longitudinal studies investigating the prognostic value of RBP4 are especially needed in children and adolescents predisposed to developing these conditions.

\section{Declaration of interest}

The authors declare that there is no conflict of interest that could be perceived as prejudicing the impartiality of the research reported.

\section{Funding}

This work is funded by the German Research Association (GRK 1041 'Molecular Diabetology and Endocrinology in Medicine') and Slovenian Research Agency (P3-0343). P Fischer-Posovszky receives a Margarete von Wrangell scholarship financed by the Ministry of Science, Research and Arts Baden-Wurttemberg, and the European Social Fund.

\section{References}

1 Sen Y, Kandemir N, Alikasifoglu A, Gonc N \& Ozon A. Prevalence and risk factors of metabolic syndrome in obese children and adolescents: the role of the severity of obesity. European Journal of Pediatrics 2008167 1183-1189. (doi:10.1007/s00431-0070658-x) 
2 D'Adamo E, Santoro N \& Caprio S. Metabolic syndrome in pediatrics: old concepts revised, new concepts discussed. Endocrinology and Metabolism Clinics of North America 200938 549-563. (doi:10.1016/j.ecl.2009.06.002)

3 Ahima RS. Adipose tissue as an endocrine organ. Obesity 200614 (Suppl 5) 242S-249S. (doi:10.1038/oby.2006.317)

4 Kershaw EE \& Flier JS. Adipose tissue as an endocrine organ. Journal of Clinical Endocrinology and Metabolism $2004 \mathbf{8 9}$ 2548-2556. (doi:10.1210/jc.2004-0395)

5 Fischer-Posovszky P, Wabitsch M \& Hochberg Z. Endocrinology of adipose tissue - an update. Hormone and Metabolic Research 2007 39 314-321. (doi:10.1055/s-2007-976539)

6 Esteve E, Ricart W \& Fernandez-Real JM. Adipocytokines and insulin resistance: the possible role of lipocalin-2, retinol binding protein-4, and adiponectin. Diabetes Care 200932 (Suppl 2) S362-S367. (doi:10.2337/dc09-S340)

7 Galic S, Oakhill JS \& Steinberg GR. Adipose tissue as an endocrine organ. Molecular and Cellular Endocrinology 2010316 129-139. (doi:10.1016/j.mce.2009.08.018)

8 Yang Q, Graham TE, Mody N, Preitner F, Peroni OD, Zabolotny JM, Kotani K, Quadro L \& Kahn BB. Serum retinol binding protein 4 contributes to insulin resistance in obesity and type 2 diabetes. Nature 2005436 356-362. (doi:10.1038/nature03711)

9 Janke J, Engeli S, Boschmann M, Adams F, Bohnke J, Luft FC, Sharma AM \& Jordan J. Retinol-binding protein 4 in human obesity. Diabetes 200655 2805-2810. (doi:10.2337/db06-0616)

10 Yao-Borengasser A, Varma V, Bodles AM, Rasouli N, Phanavanh B, Lee MJ, Starks T, Kern LM, Spencer HJ III, Rashidi AA, McGehee RE Jr, Fried SK \& Kern PA. Retinol binding protein 4 expression in humans: relationship to insulin resistance, inflammation, and response to pioglitazone. Journal of Clinica Endocrinology and Metabolism 200792 2590-2597. (doi:10. 1210/jc.2006-0816)

11 Broch M, Vendrell J, Ricart W, Richart C \& Fernandez-Real JM. Circulating retinol-binding protein-4, insulin sensitivity, insulin secretion, and insulin disposition index in obese and nonobese subjects. Diabetes Care 200730 1802-1806. (doi:10.2337/dc062034)

12 Abel ED, Peroni O, Kim JK, Kim YB, Boss O, Hadro E, Minnemann T, Shulman GI \& Kahn BB. Adipose-selective targeting of the GLUT4 gene impairs insulin action in muscle and liver. Nature $2001 \mathbf{4 0 9} 729-733$. (doi:10.1038/35055575)

13 Gnudi L, Shepherd PR \& Kahn BB. Over-expression of GLUT4 selectively in adipose tissue in transgenic mice: implications for nutrient partitioning. Proceedings of the Nutrition Society 199655 191-199. (doi:10.1079/PNS19960020)

14 Flower DR. The lipocalin protein family: structure and function. Biochemical Journal 1996318 1-14.

15 Meigs JB, Panhuysen CI, Myers RH, Wilson PW \& Cupples LA. A genome-wide scan for loci linked to plasma levels of glucose and $\mathrm{HbA}(1 \mathrm{c})$ in a community-based sample of Caucasian pedigrees: the Framingham Offspring Study. Diabetes 200251 833-840. (doi:10.2337/diabetes.51.3.833)

16 Duggirala R, Blangero J, Almasy L, Dyer TD, Williams KL, Leach RJ, O'Connell P \& Stern MP. Linkage of type 2 diabetes mellitus and of age at onset to a genetic location on chromosome 10q in Mexican Americans. American Journal of Human Genetics 199964 1127-1140. (doi:10.1086/302316)

17 Colantuoni V, Romano V, Bensi G, Santoro C, Costanzo F, Raugei G \& Cortese R. Cloning and sequencing of a full length cDNA coding for human retinol-binding protein. Nucleic Acids Research 198311 7769-7776. (doi:10.1093/nar/11.22.7769)

18 Jaconi S, Rose K, Hughes GJ, Saurat JH \& Siegenthaler G. Characterization of two post-translationally processed forms of human serum retinol-binding protein: altered ratios in chronic renal failure. Journal of Lipid Research 199536 1247-1253.

19 Tsutsumi C, Okuno M, Tannous L, Piantedosi R, Allan M, Goodman DS \& Blaner WS. Retinoids and retinoid-binding protein expression in rat adipocytes. Journal of Biological Chemistry 1992 267 1805-1810.
20 Zovich DC, Orologa A, Okuno M, Kong LW, Talmage DA, Piantedosi R, Goodman DS \& Blaner WS. Differentiation-dependent expression of retinoid-binding proteins in BFC-1 beta adipocytes. Journal of Biological Chemistry 1992267 13884-13889.

21 Newcomer ME \& Ong DE. Plasma retinol binding protein: structure and function of the prototypic lipocalin. Biochimica et Biophysica Acta 20001482 57-64. (doi:10.1016/S0167-4838(00)00150-3)

22 Erikstrup C, Mortensen OH, Nielsen AR, Fischer CP, Plomgaard P, Petersen AM, Krogh-Madsen R, Lindegaard B, Erhardt JG, Ullum H, Benn CS \& Pedersen BK. RBP-to-retinol ratio, but not total RBP, is elevated in patients with type 2 diabetes. Diabetes, Obesity $\mathcal{E}$ Metabolism 200911 204-212. (doi:10.1111/j.1463-1326.2008.00901.x)

23 Goodman AB. Retinoid receptors, transporters, and metabolizers as therapeutic targets in late onset Alzheimer disease. Journal of Cellular Physiology 2006209 598-603. (doi:10.1002/jcp.20784)

24 Mody N, Graham TE, Tsuji Y, Yang Q \& Kahn BB. Decreased clearance of serum retinol-binding protein and elevated levels of transthyretin in insulin-resistant ob/ob mice. American Journal of Physiology. Endocrinology and Metabolism 2008294 E785-E793. (doi:10.1152/ajpendo.00521.2007)

25 Frey SK, Spranger J, Henze A, Pfeiffer AF, Schweigert FJ \& Raila J. Factors that influence retinol-binding protein 4-transthyretin interaction are not altered in overweight subjects and overweight subjects with type 2 diabetes mellitus. Metabolism $2009 \mathbf{5 8}$ 1386-1392. (doi:10.1016/j.metabol.2009.05.003)

26 Fernandez-Real JM, Moreno JM \& Ricart W. Circulating retinolbinding protein- 4 concentration might reflect insulin resistanceassociated iron overload. Diabetes 200857 1918-1925. (doi:10. 2337/db08-0041)

27 Sivaprasadarao A \& Findlay JB. The interaction of retinol-binding protein with its plasma-membrane receptor. Biochemical Journal $1988255561-569$.

28 Matarese V \& Lodish HF. Specific uptake of retinol-binding protein by variant F9 cell lines. Journal of Biological Chemistry 1993268 18859-18865.

29 Kawaguchi R, Yu J, Honda J, Hu J, Whitelegge J, Ping P, Wiita P, Bok D \& Sun H. A membrane receptor for retinol binding protein mediates cellular uptake of vitamin A. Science $2007 \mathbf{3 1 5} 820-$ 825. (doi:10.1126/science.1136244)

30 Chambon P. A decade of molecular biology of retinoic acid receptors. FASEB Journal 199610 940-954.

31 Nair AK, Sugunan D, Kumar H \& Anilkumar G. Case-control analysis of SNPs in GLUT4, RBP4 and STRA6: association of SNPs in STRA6 with type 2 diabetes in a South Indian population. PLoS ONE 20105 e11444. (doi:10.1371/journal.pone.0011444)

32 Graham TE, Yang Q, Bluher M, Hammarstedt A, Ciaraldi TP, Henry RR, Wason CJ, Oberbach A, Jansson PA, Smith U \& Kahn BB. Retinol-binding protein 4 and insulin resistance in lean, obese, and diabetic subjects. New England Journal of Medicine 2006 354 2552-2563. (doi:10.1056/NEJMoa054862)

33 Kovacs P, Geyer M, Berndt J, Kloting N, Graham TE, Bottcher Y, Enigk B, Tonjes A, Schleinitz D, Schon MR, Kahn BB, Bluher M \& Stumvoll M. Effects of genetic variation in the human retinol binding protein-4 gene (RBP4) on insulin resistance and fat depotspecific mRNA expression. Diabetes 200756 3095-3100. (doi:10. 2337/db06-1647)

34 Munkhtulga L, Nagashima S, Nakayama K, Utsumi N, Yanagisawa Y, Gotoh T, Omi T, Kumada M, Zolzaya K, Lkhagvasuren T, Kagawa Y, Fujiwara H, Hosoya Y, Hyodo M, Horie H, Kojima M, Ishibashi S \& Iwamoto S. Regulatory SNP in the RBP4 gene modified the expression in adipocytes and associated with BMI. Obesity 201018 1006-1014. (doi:10. 1038/oby.2009.358)

35 Cho YM, Youn BS, Lee H, Lee N, Min SS, Kwak SH, Lee HK \& Park KS. Plasma retinol-binding protein-4 concentrations are elevated in human subjects with impaired glucose tolerance and type 2 diabetes. Diabetes Care 200629 2457-2461. (doi:10. 2337/dc06-0360)

36 Gavi S, Stuart LM, Kelly P, Melendez MM, Mynarcik DC, Gelato MC \& McNurlan MA. Retinol-binding protein 4 is associated with 
insulin resistance and body fat distribution in nonobese subjects without type 2 diabetes. Journal of Clinical Endocrinology and Metabolism 200792 1886-1890. (doi:10.1210/jc.2006-1815)

37 Jia W, Wu H, Bao Y, Wang C, Lu J, Zhu J \& Xiang K. Association of serum retinol-binding protein 4 and visceral adiposity in Chinese subjects with and without type 2 diabetes. Journal of Clinical Endocrinology and Metabolism 200792 3224-3229. (doi:10. 1210/jc.2007-0209)

38 Lee JW, Im JA, Lee HR, Shim JY, Youn BS \& Lee DC. Visceral adiposity is associated with serum retinol binding protein-4 levels in healthy women. Obesity 200715 2225-2232. (doi:10.1038/ oby.2007.264)

39 Kelly KR, Kashyap SR, O'Leary VB, Major J, Schauer PR \& Kirwan JP. Retinol-binding protein 4 (RBP4) protein expression is increased in omental adipose tissue of severely obese patients. Obesity 201018 663-666. (doi:10.1038/oby.2009.328)

40 Kloting N, Graham TE, Berndt J, Kralisch S, Kovacs P, Wason CJ, Fasshauer M, Schon MR, Stumvoll M, Bluher M \& Kahn BB. Serum retinol-binding protein is more highly expressed in visceral than in subcutaneous adipose tissue and is a marker of intra-abdominal fat mass. Cell Metabolism 2007 6 79-87. (doi:10.1016/j.cmet. 2007.06.002)

41 Hermsdorff HH, Zulet MA, Puchau B \& Martinez JA. Central adiposity rather than total adiposity measurements are specifically involved in the inflammatory status from healthy young adults. Inflammation 201034 161-170. (doi:10.1007/s10753-0109219-y)

42 Haider DG, Schindler K, Prager G, Bohdjalian A, Luger A, Wolzt M \& Ludvik B. Serum retinol-binding protein 4 is reduced after weight loss in morbidly obese subjects. Journal of Clinical Endocrinology and Metabolism 200792 1168-1171. (doi:10.1210/jc.2006-1839)

43 Lee JW, Lee HR, Shim JY, Im JA \& Lee DC. Abdominal visceral fat reduction is associated with favorable changes of serum retinol binding protein-4 in nondiabetic subjects. Endocrine Journal 2008 55 811-818. (doi:10.1507/endocrj.K08E-030)

44 Vitkova M, Klimcakova E, Kovacikova M, Valle C, Moro C, Polak J, Hanacek J, Capel F, Viguerie N, Richterova B, Bajzova M, Hejnova J, Stich V \& Langin D. Plasma levels and adipose tissue messenger ribonucleic acid expression of retinol-binding protein 4 are reduced during calorie restriction in obese subjects but are not related to diet-induced changes in insulin sensitivity. Journal of Clinical Endocrinology and Metabolism 200792 2330-2335. (doi:10.1210/jc.2006-2668)

45 Basualdo CG, Wein EE \& Basu TK. Vitamin A (retinol) status of first nation adults with non-insulin-dependent diabetes mellitus. Journal of the American College of Nutrition 199716 39-45.

46 Abahusain MA, Wright J, Dickerson JW \& de Vol EB. Retinol, alphatocopherol and carotenoids in diabetes. European Journal of Clinical Nutrition 199953 630-635. (doi:10.1038/sj.ejcn.1600825)

47 Kloting N, Fasshauer M, Dietrich A, Kovacs P, Schon MR, Kern M, Stumvoll M \& Bluher M. Insulin-sensitive obesity. American Journal of Physiology. Endocrinology and Metabolism 2010299 E506-E515. (doi:10.1152/ajpendo.00586.2009)

48 Craig RL, Chu WS \& Elbein SC. Retinol binding protein 4 as a candidate gene for type 2 diabetes and prediabetic intermediate traits. Molecular Genetics and Metabolism 200790 338-344. (doi:10.1016/j.ymgme.2006.11.003)

49 Munkhtulga L, Nakayama K, Utsumi N, Yanagisawa Y, Gotoh T, Omi T, Kumada M, Erdenebulgan B, Zolzaya K, Lkhagvasuren T \& Iwamoto S. Identification of a regulatory SNP in the retinol binding protein 4 gene associated with type 2 diabetes in Mongolia. Human Genetics 2007120 879-888. (doi:10.1007/ s00439-006-0264-4)

$50 \mathrm{Ku}$ YH, Han KA, Ahn H, Kwon H, Koo BK, Kim HC \& Min KW. Resistance exercise did not alter intramuscular adipose tissue but reduced retinol-binding protein- 4 concentration in individuals with type 2 diabetes mellitus. Journal of International Medical Research 201038 782-791.

51 Qi Q, Yu Z, Ye X, Zhao F, Huang P, Hu FB, Franco OH, Wang J, Li H, Liu Y \& Lin X. Elevated retinol-binding protein 4 levels are associated with metabolic syndrome in Chinese people. Journal of Clinical Endocrinology and Metabolism 200792 4827-4834. (doi:10.1210/jc.2007-1219)

52 Makino S, Fujiwara M, Suzukawa K, Handa H, Fujie T, Ohtaka Y, Komatsu Y, Aoki Y, Maruyama H, Terada Y, Hashimoto K \& Sugimoto T. Visceral obesity is associated with the metabolic syndrome and elevated plasma retinol binding protein-4 level in obstructive sleep apnea syndrome. Hormone and Metabolic Research 200941 221-226. (doi:10.1055/s-0028-1100411)

53 Lim S, Yoon JW, Choi SH, Park YJ, Lee JJ, Park JH, Lee SB, Kim KW, Lim JY, Kim YB, Park KS, Lee HK, Cho SI \& Jang HC. Combined impact of adiponectin and retinol-binding protein 4 on metabolic syndrome in elderly people: the Korean Longitudinal Study on Health and Aging. Obesity 201018 826-832. (doi:10.1038/oby. 2009.232)

54 Wu Y, Li H, Loos RJ, Qi Q, Hu FB, Liu Y \& Lin X. RBP4 variants are significantly associated with plasma RBP4 levels and hypertriglyceridemia risk in Chinese Hans. Journal of Lipid Research 200950 1479-1486. (doi:10.1194/jlr.P900014-JLR200)

55 Bobbert T, Raila J, Schwarz F, Mai K, Henze A, Pfeiffer AF, Schweigert FJ \& Spranger J. Relation between retinol, retinolbinding protein 4 , transthyretin and carotid intima media thickness. Atherosclerosis 2010213 549-551. (doi:10.1016/j. atherosclerosis.2010.07.063)

56 Sasaki M, Otani T, Kawakami M \& Ishikawa SE. Elevation of plasma retinol-binding protein 4 and reduction of plasma adiponectin in subjects with cerebral infarction. Metabolism 201059 527-532. (doi:10.1016/j.metabol.2009.08.015)

57 Ingelsson E, Sundstrom J, Melhus H, Michaelsson K, Berne C, Vasan RS, Riserus U, Blomhoff R, Lind L \& Arnlov J. Circulating retinol-binding protein 4 , cardiovascular risk factors and prevalent cardiovascular disease in elderly. Atherosclerosis 2009 206 239-244. (doi:10.1016/j.atherosclerosis.2009.02.029)

58 Mallat Z, Simon T, Benessiano J, Clement K, Taleb S, Wareham NJ, Luben R, Khaw KT, Tedgui A \& Boekholdt SM. Retinol-binding protein 4 and prediction of incident coronary events in healthy men and women. Journal of Clinical Endocrinology and Metabolism 200994 255-260. (doi:10.1210/jc.2008-0253)

59 Choi KM, Yannakoulia M. Park MS, Cho GJ. Kim JH, Lee SH, Hwang TG, Yang SJ, Kim TN, Yoo HJ, Baik SH, Kim SM \& Mantzoros CS. Serum adipocyte fatty acid-binding protein, retinolbinding protein 4 , and adiponectin concentrations in relation to the development of the metabolic syndrome in Korean boys: a 3-y prospective cohort study. American Journal of Clinical Nutrition 20119 19-26. (doi:10.3945/ajcn.2010.29667)

60 Aust G, Uptaite-Patapoviene M, Scholz M, Richter O, Rohm S \& Bluher M. Circulating Nampt and RBP4 levels in patients with carotid stenosis undergoing carotid endarterectomy (CEA). Clinica Chimica Acta 2011412 1195-1200. (doi:10.1016/j.cca.2011.03.008)

61 Aeberli I, Biebinger R, Lehmann R, L'allemand D, Spinas GA \& Zimmermann MB. Serum retinol-binding protein 4 concentration and its ratio to serum retinol are associated with obesity and metabolic syndrome components in children. Journal of Clinical Endocrinology and Metabolism 200792 4359-4365. (doi:10. 1210/jc.2007-0468)

62 Balagopal P, Graham TE, Kahn BB, Altomare A, Funanage V \& George D. Reduction of elevated serum retinol binding protein in obese children by lifestyle intervention: association with subclinical inflammation. Journal of Clinical Endocrinology and Metabolism 200792 1971-1974. (doi:10.1210/jc.2006-2712)

63 Reinehr T, Stoffel-Wagner B \& Roth CL. Retinol-binding protein 4 and its relation to insulin resistance in obese children before and after weight loss. Journal of Clinical Endocrinology and Metabolism 200893 2287-2293. (doi:10.1210/jc.2007-2745)

64 Yeste D, Vendrell J, Tomasini R, Gallart LL, Clemente M, Simon I, Albisu M, Gussinye M, Audi L \& Carrascosa A. Retinol-binding protein 4 levels in obese children and adolescents with glucose intolerance. Hormone Research in Pediatrics 201073 335-340. (doi:10.1159/000308165) 
65 Kim IK, Lee HJ, Kang JH \& Song J. Relationship of serum retinolbinding protein 4 with weight status and lipid profile among Korean children and adults. European Journal of Clinical Nutrition 201165 226-233. (doi:10.1038/ejcn.2010.251)

66 Friebe D, Neef M, Erbs S, Dittrich K, Kratzsch J, Kovacs P, Bluher M, Kiess W \& Korner A. Retinol binding protein 4 (RBP4) is primarily associated with adipose tissue mass in children. International Journal of Pediatric Obesity 20106 e346-e352.

67 Lee DC, Lee JW \& Im JA. Association of serum retinol binding protein 4 and insulin resistance in apparently healthy adolescents. Metabolism 200756 327-331. (doi:10.1016/j.metabol.2006.10.011)

68 Santoro N, Perrone L, Cirillo G, Brienza C, Grandone A, Cresta N \& Miraglia del GE. Variations of retinol binding protein 4 levels are not associated with changes in insulin resistance during puberty. Journal of Endocrinological Investigation 200932 411-414.

69 Goodman E, Graham TE, Dolan LM, Daniels SR, Goodman ER \& Kahn BB. The relationship of retinol binding protein 4 to changes in insulin resistance and cardiometabolic risk in overweight black adolescents. Journal of Pediatrics 2009154 67-73. (doi:10.1016/ j.jpeds.2008.07.018)

70 Giacomozzi C, Ghirri P, Lapolla R, Bartoli A, Scire G, Serino L, Germani D, Boldrini A \& Cianfarani S. Retinol-binding protein 4 in neonates born small for gestational age. Journal of Endocrinological Investigation $201033218-221$.

71 Kanaka-Gantenbein C, Margeli A, Pervanidou P, Sakka S, Mastorakos G, Chrousos GP \& Papassotiriou I. Retinol-binding protein 4 and lipocalin-2 in childhood and adolescent obesity: when children are not just "small adults". Clinical Chemistry 2008 54 1176-1182. (doi:10.1373/clinchem.2007.099002)

72 Ulgen F, Herder C, Kuhn MC, Willenberg HS, Schott M, Scherbaum WA \& Schinner S. Association of serum levels of retinol-binding protein 4 with male sex but not with insulin resistance in obese patients. Archives of Physiology and Biochemistry 2010116 57-62. (doi:10.3109/13813451003631421)

73 Kos K, Wong S, Tan B, Kerrigan D, Randeva H, Pinkney J \& Wilding J. Human RBP4 adipose tissue expression is gender specific and influenced by leptin. Clinical Endocrinology $2010 \mathbf{7 4}$ 197-205. (doi:10.1111/j.1365-2265.2010.03892.x)

74 Promintzer M, Krebs M, Todoric J, Luger A, Bischof MG, Nowotny P, Wagner O, Esterbauer $\mathrm{H} \&$ Anderwald C. Insulin resistance is unrelated to circulating retinol binding protein and protein C inhibitor. Journal of Clinical Endocrinology and Metabolism 200792 4306-4312. (doi:10.1210/jc.2006-2522)

75 von Eynatten M, Lepper PM, Liu D, Lang K, Baumann M, Nawroth PP, Bierhaus A, Dugi KA, Heemann U, Allolio B \& Humpert PM. Retinol-binding protein 4 is associated with components of the metabolic syndrome, but not with insulin resistance, in men with type 2 diabetes or coronary artery disease. Diabetologia 200750 1930-1937. (doi:10.1007/s00125-0070743-8)

76 Ribel-Madsen R, Friedrichsen M, Vaag A \& Poulsen P. Retinolbinding protein 4 in twins: regulatory mechanisms and impact of circulating and tissue expression levels on insulin secretion and action. Diabetes 200958 54-60. (doi:10.2337/db08-1019)

77 Chavez AO, Coletta DK, Kamath S, Cromack DT, Monroy A, Folli F, DeFronzo RA \& Tripathy D. Retinol-binding protein 4 is associated with impaired glucose tolerance but not with whole body or hepatic insulin resistance in Mexican Americans. American Journal of Physiology. Endocrinology and Metabolism 2009296 E758-E764. (doi:10.1152/ajpendo.90737.2008)

78 Henze A, Frey SK, Raila J, Tepel M, Scholze A, Pfeiffer AF, Weickert MO, Spranger J \& Schweigert FJ. Evidence that kidney function but not type 2 diabetes determines retinol-binding protein 4 serum levels. Diabetes 200857 3323-3326. (doi:10. 2337/db08-0866)

79 Murata M, Saito T, Otani T, Sasaki M, Ikoma A, Toyoshima H, Kawakami M \& Ishikawa SE. An increase in serum retinol-binding protein 4 in the type 2 diabetic subjects with nephropathy. Endocrine Journal 200956 287-294. (doi:10.1507/endocrj.K08E-242)
80 Akbay E, Muslu N, Nayir E, Ozhan O \& Kiykim A. Serum retinol binding protein 4 level is related with renal functions in type 2 diabetes. Journal of Endocrinological Investigation 201033 725-729.

81 Ziegelmeier M, Bachmann A, Seeger J, Lossner U, Kratzsch J, Bluher M, Stumvoll M \& Fasshauer M. Serum levels of adipokine retinol-binding protein-4 in relation to renal function. Diabetes Care 200730 2588-2592. (doi:10.2337/dc07-0275)

82 Nishizawa H, Shimomura I, Kishida K, Maeda N, Kuriyama H, Nagaretani H, Matsuda M, Kondo H, Furuyama N, Kihara S, Nakamura T, Tochino Y, Funahashi T \& Matsuzawa Y. Androgens decrease plasma adiponectin, an insulin-sensitizing adipocytederived protein. Diabetes 200251 2734-2741. (doi:10.2337/ diabetes.51.9.2734)

83 Wabitsch M, Blum WF, Muche R, Braun M, Hube F, Rascher W, Heinze E, Teller W \& Hauner H. Contribution of androgens to the gender difference in leptin production in obese children and adolescents. Journal of Clinical Investigation 1997100 808-813. (doi:10.1172/JCI119595)

84 Stefan N, Hennige AM, Staiger H, Machann J, Schick F, Schleicher E, Fritsche A \& Haring HU. High circulating retinolbinding protein 4 is associated with elevated liver fat but not with total, subcutaneous, visceral, or intramyocellular fat in humans. Diabetes Care 200730 1173-1178. (doi:10.2337/dc06-2342)

85 Takebayashi K, Suetsugu M, Wakabayashi S, Aso Y \& Inukai T. Retinol binding protein-4 levels and clinical features of type 2 diabetes patients. Journal of Clinical Endocrinology and Metabolism 200792 2712-2719. (doi:10.1210/jc.2006-1249)

86 An C, Wang H, Liu X, Li Y, Su Y, Gao X \& Jiang W. Serum retinolbinding protein 4 is elevated and positively associated with insulin resistance in postmenopausal women. Endocrine Journal 200956 987-996. (doi:10.1507/endocrj.K09E-096)

87 Suh JB, Kim SM, Cho GJ, Choi KM, Han JH \& Taek GH. Elevated serum retinol-binding protein 4 is associated with insulin resistance in older women. Metabolism $2010 \mathbf{5 9} 118-122$. (doi:10.1016/j.metabol.2009.06.025)

88 Weiping L, Qingfeng C, Shikun M, Xiurong L, Hua Q, Xiaoshu B, Suhua Z \& Qifu L. Elevated serum RBP4 is associated with insulin resistance in women with polycystic ovary syndrome. Endocrine 200630 283-287. (doi:10.1007/s12020-006-0006-3)

89 Aigner E, Bachofner N, Klein K, De Geyter C, Hohla F, Patsch W \& Datz C. Retinol-binding protein 4 in polycystic ovary syndromeassociation with steroid hormones and response to pioglitazone treatment. Journal of Clinical Endocrinology and Metabolism 2009 94 1229-1235. (doi:10.1210/jc.2008-2156)

90 Tan BK, Chen J, Lehnert H, Kennedy R \& Randeva HS. Raised serum, adipocyte, and adipose tissue retinol-binding protein 4 in overweight women with polycystic ovary syndrome: effects of gonadal and adrenal steroids. Journal of Clinical Endocrinology and Metabolism 200792 2764-2772. (doi:10.1210/jc.2007-0091)

91 Ost A, Danielsson A, Liden M, Eriksson U, Nystrom FH \& Stralfors P. Retinol-binding protein-4 attenuates insulin-induced phosphorylation of IRS1 and ERK1/2 in primary human adipocytes. FASEB Journal 200721 3696-3704. (doi:10.1096/fj.07-8173com)

92 Sell H \& Eckel J. Regulation of retinol binding protein 4 production in primary human adipocytes by adiponectin, troglitazone and TNF-alpha. Diabetologia 200750 2221-2223. (doi:10.1007/ s00125-007-0764-3)

93 Bajzova M, Kovacikova M, Vitkova M, Klimcakova E, Polak J, Kovacova Z, Viguerie N, Vedral T, Mikulasek L, Sramkova P, Srp A, Hejnova J, Langin D \& Stich V. Retinol-binding protein 4 expression in visceral and subcutaneous fat in human obesity. Physiological Research 200857 927-934.

Received 12 May 2011

Revised version received 12 July 2011

Accepted 10 August 2011 